\title{
76. Küresel ekonomi piyasalarında sıkça kullanılan bazı terimlere Türkçe karșılıklar II
}

\section{Emrah ERIŞ1}

Şahap BULAK²

APA: Eriş, E.; Bulak, Ş. (2021). Küresel ekonomi piyasalarında sıkça kullanılan bazı terimlere Türkçe karşılıklar II. RumeliDE Dil ve Edebiyat Araşturmaları Dergisi, (24), 1272-1285. DOI: 10.2900o/rumelide.997968.

$\ddot{O} \mathbf{z}$

Günümüzde en hızlı küreselleşen alanlardan biri olan ekonomi sayesinde hayatımıza her gün yeni kelime, terimlerin karşıladığı birtakım kavramlar girmektedir. Bu kavramları karşılayan kelime ve terimler başta çeviri yoluyla dilimize girmekte, daha sonra yaygınlaşıp kendilerine algı oluşturarak dile yerleşmektedirler. Söz konusu alıntı kelime ve terimlerin toplumun geneli tarafindan anlaşılması, öğrenilmesi öğretilmesi için bunların ifade ettiği anlamı karşılayan Türkçe kelime ve terimlerle ifade edilmesi gerekir. Bu da dilimize yeni girmiş ve henüz yaygınlaşmamış kelime ve terimlere uygun Türkçe karşılıklar bulup bunların kullanımlarını yaygınlaştırmakla mümkündür. Bunun için diğer alanlarda olduğu gibi en hızlı küreselleşen alanlardan biri olan ekonomi alanında da küresel piyasalarda sıklıkla kullanılan ve dilimizde yeni yeni kullanılmaya başlanan kelime ve terimlere uygun Türkçe karşılıklar bulunmalıdır. Bu çalışmada küresel piyasalarda sıkça kullanılan ve Türkçede henüz yeni görülmeye başlanan bazı terimlere Türkçe karşılıklar önerilmiştir. $\mathrm{Bu}$ karşılıklar önerilirken öncelikle alıntı terimlerin kökenleri, varsa ait oldukları dillerde tarihi gelişim ve değişim sürecinde geçirdikleri fonetik ve morfolojik değişikler açılanmış ve taşıdığı anlamlar verilmiştir. Daha sonra söz konusu terimlerin oluşumunda etkili olan etkenler üzerinde durulmuş ve çalışmaya konu olan terimlerin çoğunun oluşumunda metaforlardan yararlanıldı̆̆ı tespit edilmiştir. Bu metaforların söz konusu terimlerin ait olduğu Batı kültüründe ve Türk kültüründe ifade ettiği anlamlar verilerek benzer ve farklı yönleri irdelenmiştir. Benzer anlam taşıyan metaforlar terimlere karşılık önerilirken genellikle göz önünde bulundurulmuş, farklı anlam taşıyan metaforlar yardımıyla oluşturulan terimlere karşılık verilirken daha çok kaynak terimin ifade etiği anlam esas alınmıştır. Böylece bir yandan küresel ekonomi piyasalarında sıkça kullanılan ve dilimizde henüz yeni yeni kullanılmaya başlanan bazı terimlere Türkçe karşılıklar önerilirken diğer yandan ülkemizde hemen her alanda görülen ve gittikçe bir istilaya dönüşen terimlerde yabancılaşmaya dikkat çekilmeye çalışılmıştır.

Anahtar kelimeler: Türkçe, ekonomi, metafor, terimler, Türkçe terimler

\section{Turkish equivalents for some frequency terms in global economy markets II}

\author{
Abstract \\ Thanks to the economy, which is one of the fastest globalizing areas today, new words and terms come \\ into our lives every day. Words and terms that meet these concepts first enter our language through \\ Doç. Dr., Sïrt Üniversitesi, Yabancı Diller Yüksekokulu, Mütercim Tercümanlık (Siirt, Türkiye) \\ emraheris1@hotmail.com, ORCID ID: oooo-0oo1-6753-9746 [Araştırma makalesi, Makale kayıt tarihi: 16.07.2021-kabul \\ tarihi: 20.09.2021; DOI: 10.29000/rumelide.997968] \\ Doç. Dr., Siirt Üniversitesi, Fen Edebiyat Fakültesi, Türk Dili ve Edebiyatı Bölümü (Siirt, Türkiye), \\ sahapbulak@gmail.com, ORCID ID: 000o-0002-6459-3680 \\ Adres | Address \\ RumeliDE Dil ve Edebiyat Araştırmaları Dergisi $\quad$ RumeliDE Journal of Language and Literature Studies \\ Osmanağa Mahallesi, Mürver Çiçeği Sokak, No:14/8 Osmanağa Mahallesi, Mürver Çiçeği Sokak, No:14/8 \\ Kadıköy - İSTANBUL / TÜRKIYE 34714 Kadıköy - ISTANBUL / TURKEY 34714 \\ e-posta: editor@rumelide.com e-mail: editor@rumelide.com, \\ tel: +90 505 7958124, +90 216773 o 616 phone: +90 505 7958124, +90 2167730616
}


translation, then become widespread and settle in the language by creating a perception for themselves. In order to be understood, learned and taught by the society in general, these borrowed words and terms must be expressed with Turkish words and terms that meet the meaning they express. This is possible by finding appropriate Turkish equivalents for words and terms that have just entered our language and have not yet become widespread, and popularize their use. For this, as in other fields, in the field of economy, which is one of the fastest globalizing fields, Turkish equivalents should be found for words and terms that are frequently used in global markets and that have just begun to be used in our language. In this study, Turkish equivalents have been proposed for some terms that are frequently used in global markets and have just begun to appear in Turkish. While suggesting these equivalents, first of all, the origins of the borrowed terms, the phonetic and morphological changes they have undergone during the historical development and change in the languages they belong to are explained and their meanings are given. Then, the factors that are effective in the formation of the terms in question were emphasized and it was determined that metaphors were used in the formation of most of the terms that were the subject of the study. The similar and different aspects of these metaphors were examined by giving the meanings of these terms in the Western culture and Turkish culture to which they belong. Metaphors with similar meanings are generally taken into consideration when suggesting terms, while terms created with the help of metaphors with different meanings are mostly based on the meaning expressed by the source term. Thus, on the one hand, Turkish equivalents have been proposed for some terms that are frequently used in global economic markets and have just begun to be used in our language, on the other hand, there has been an attempt to draw attention to the issue of "foreignization in terms" that appears to be common in almost every field in our country and turns into an invasion.

Keywords: Turkish, economy, metaphor, terms, Turkish terms

\section{Giriş}

Tarih boyunca dil insanoğlu için en mükemmel ve vazgeçilmez iletişim aracı olmuş, oluyor ve olmaya da devam edecektir. Ancak gerçek olan şu ki insanların duygu ve düşünceleri, yaşadığı coğrafyalar ve bağlı oldukları gelenek, görenek ve kültürleri zamanla dillerinde büyük değişimlere sebep olacak etkilerde bulunur. "Geçen yılın kelimeleri geçen yılın diline aittir ve yeni yılın kelimeleri yeni bir ses bekler." diyen T. S. Eliot (1941) bu etkenler dışında zamanın da dili değiştirdiğine dikkat çeker. Tabii bu etkenlere bir de günümüzde kaçınılmaz olan küreselleşmenin etkisini eklemek gerekir. Nitekim içerisinde bulunduğumuz dijital çağın en önemli olgularından hatta en önemli olgusu olan küreselleşme olgusu, hayatımızı her yönüyle kuşatmıştır. Doğası gereği çok çeşitlilik arz eden bu kuşatmanın merkezine dil konulabilir. Nitekim yapılan uluslararası anlaşmalar, dijital çağın gerektirdiği haber sunumları, dergiler, kitaplar kısaca her türlü yayım ve yayın dünyanın hemen her yerinde yaşayan insanlara dil aracılığıyla iletilmektedir. Zira dünyanın küresel bir köye dönüştüğü günümüzde bireysel hatta sosyal soyutlanma bile neredeyse imkânsız hale gelmiştir. Her alanda olanca hızıyla yaşanan küreselleşmeden yaşamın merkezinde yer alan dilin etkilenmemesi düşünülemez. Bu etkilenme, genellikle kelime, terim veya dil kuralı alışverişi şeklinde kendini gösterir. Kelime alışverişi, ülkeler arasında gelişen ekonomik ve kültürel ilişkilerin doğal sonucudur. Bu alışveriş istila şeklini aldığı ya da terim veya dili kuralı ithal etme boyutuna geldiği zaman diller için bir felakete dönüşür. Dolayısıyla hızlı küreselleşmenin dilde bir felakete dönüşmemesi için makul düzeyde kelime alışverişi ile sınırlı kalması, terim ve dil kuralı alma boyutuna taşınmamalıdır.

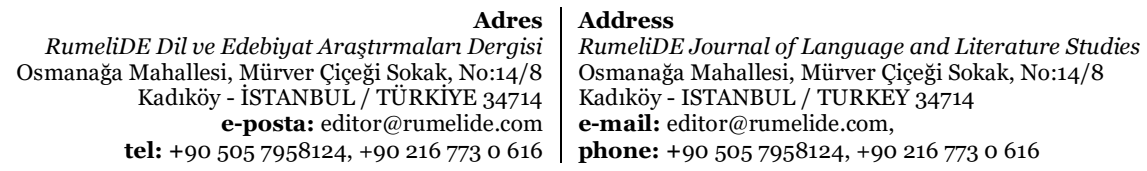

Adres
RumeliDE Dil ve Edebiyat Araştırmaları Dergisi

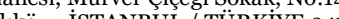
tel: +90 505 7958124, +902167730616
Address

Osmanağa Mahallesi, Mürver Ciçeği Sokak, No:14/8

-mail: editor@rumelide.com,

phone: +90 505 7958124, +90 2167730616 
İslam medeniyetiyle tanıştıkları ilk dönemlerde Arapçayı bilim dili, Farsçayı edebiyat dili olarak kullanan Türkler, bir yandan bu dillerde yazılan bilim ve sanat eserlerini Türkçeye çevirirken diğer yandan çeşitli bilim ve sanat dallarında önemli telif eserler ortaya koydular. Bu eserlerin sayı ve çeşitleri arttıkça Arapça ve Farsça terimlerin yanında Türkçe terimler türetilmeye ve kullanılmaya başlandıysa da XIX. yüzylla kadar bilim ve sanatta genellikle İslam medeniyeti terminolojisi kullanıldı. Tanzimat döneminde aydınlar Batı medeniyetine yönelince sosyal ve kültürel alanda olduğu gibi, bilim ve sanat alanında da Batı medeniyetini esas alan yeni bir dönem başladı. Bu dönemde Batıda öğrenim gören aydınlar, yeni karşılaştıkları kavramları karşılamak için Türkçe terim türetip kullanma yerine kolaya kaçıp Batı dillerine özellikle Fransızcaya ait terimleri olduğu gibi alma yoluna gittiler. Hatta var olan Arapça ve Farsça terimlerin yerine bile Batı dillerine ait terimler kullanmaya başladılar. Buna Batı dillerinden yapılan çeviriler ve Fransızca eğitim vermeye başlayan okullardaki ders kitapları da eklenince o zamana kadar kendini iyiden iyiye hissettiren terimlerde yabancılaşma büyük bir ivme kazandı (Bulak 2017:1-3).

Dilde sadeleşme gibi terim çalışmaları da planlı ve bilinçli olarak ilk kez Cumhuriyet döneminde Türk Dil Kurumu eliyle başlatıldı. Terim çalışmalarını ıstılah kolu vasıtası ile yürüten Türk Dil Kurumu, bu dönemden itibaren terim çalışmalarını hızlandırarak Türkçe terimler türetip türetilen yeni terimleri yayma çalışmalarına ağırlık verdi. Bu kapsamda Türkçe kök ve eklerden çok sayıda yeni terim türetilip çeşitli bilim ve sanat dallarında terim sözlükleri hazırlanarak önemli bir mesafe alındı. Ancak bir süre sonra dilde sadeleşme bilincinin zayıflaması, türetilen bazı yeni terimlerin yapı ve kuruluşlarının Türkçenin kurallarına uymaması, inandırıcılığın zedelenmesi, birtakım yakışıksız türetmelerin doğru örneklerin tutunmasını etkilemesi, kavram ve terim kargaşasına düşüleceğinden korkulması gibi sebeplerden dolayı terimlerin Türkçeleştirilmesi konusundaki şevk ve heyecan yitirilince terim çalışmaları sekteye uğradı (Zülfikar 1991:VII; Timurtaş 1966: 209). Bu sebeplerle büyük bir heyecanla başlanan ve kısa süre içinde büyük mesafe alınan terim çalışmalarına bir süreklilik kazandırılamadı. Dilde sadeleşme çalışmaları kapsamında Türkçeden atılan Arapça ve Farsça terimlerin yerine Türkçe kök ve eklerle türetilen terimler konulamayınca oluşan boşluk Batı dillerinden alınan terimlerle dolduruldu. Ayrıca Cumhuriyetin ilk yıllarında bazı bilim, sanat ve spor dallarında yeterli Türkçe ders kitabı ve kaynak kitap olmadığı için bunların yerine genellikle Batı dillerine ait kaynaklar kullanıldı. Böylece var olan terimlerin yanı sıra Batılı kaynaklardaki terimler de kullanılınca eğitim öğretimde kullanılan ders kitapları ve kaynak kitaplarda kullanılan terimlerde bolluk ve tutarsızlık sonucu keyfi uygulamalar başladı. Bu tutarsızlık ve keyfi uygulamalar baş gösterince bilim insanları ve öğretim elemanları bildiği yabancı dilin terimlerini kullanmaya başlayarak bu konuda var olan sorunu bir sorunlar yumağı haline getirdiler. Bunlara yaptıklarını cilalama kaygısıyla Türkçe karşılı̆̆ olduğu halde Batı dillerine ait terimleri kullanma özentisi de eklenince Türkçe Batı dillerine ait terimlerin istilasına uğrayarak bugünlere değin geldi (Bulak 2017:1-3).

İnsanların hayati unsurlarından olan ekonomi, bireysel ekonomi, aile ekonomisi, ülke ekonomisi ve küresel ekonomi gibi çeşitli boyutlardan oluştuğu için yeryüzünde yaşayan hemen herkesi ilgilendiren alanların başında gelmektedir. Xia Jue (2009)'e göre "Siyaset gibi ekonomi de insanoğlu ve insanlardan oluşan toplum ile yakın bir ilişki içerisinde olup günlük konuşmalarda insanların kaçınılmaz bir şekilde ekonomi ve ilgili konular hakkında konuşmasına sebep verecek büyüklükte öneme sahiptir.” Hui Fan (2017) ise, "Küresel iş ve ticaret gelişimini sürdürdükçe ülkeler ve bölgelerarası ekonomik alışverişler giderek ortak bir hal almaya başlamaktadır." diyerek ekonominin artık küresel bir olgu hale geldiğine atıfta bulunmaktadır. Fan'a göre, reklam dili, yegâne bir uygulamalı yazı yazma biçimi olup sıradan edebi eserlerde bulunan yazı biçiminden farklıdır. Marka isimleri ya da reklam iletilerinin yanlış bir şekilde çevrilmesi durumunda güvenilirlik ve tanınırlık noktasında yaşanacak kaybın telafisi mümkün

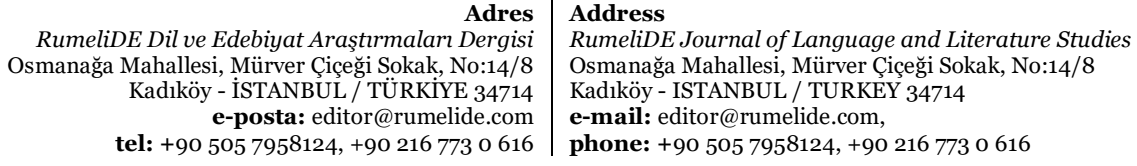


olmayan sonuçlara yol açabilir. Fan, bu ifadelerle ağır ekonomik sonuçları olan küresel ekonomi dilinin anlaşılırlığının ne denli önemli olduğunu vurgulamaktadır (2017: 39). Bu anlaşılırlık da şüphesiz alıntı kelime, terim ve kavramlarla değil, bir dilin kendi kelime, terimleriyle mümkündür.

Ekonominin en mükemmel şekliyle karşılık bulduğu küresel piyasalar, başta ekonomistler olmak üzere ekonomi ile ilgilenen herkesin takip ettiği ya da ilgi duyduğu, küresel ekonominin nabzının attığı yerdir. Bilim ve teknoloji gibi en hızlı küreselleşen alanlardan biri olan ekonomi sayesinde hayatımıza her gün yeni kavramlar girmektedir. Bu kavramları karşılayan kelime ve terimler çeviri yoluyla dilimize girdikten sonra yaygınlaşıp kendilerine algısal bir alan açıp dile yerleşmektedirler. Söz konusu alıntı kelime ve terimlerin ilgili herkes tarafindan iyi anlaşılması için bunların ifade ettiği anlamı karşılayan Türkçe kelime ve terimlerle ifade edilmesi gerekir. Bu da dilimize yeni girmiş ve henüz yaygınlaşmamış kelime ve terimlere uygun Türkçe karşılıklar bulup bunları yaygınlaştırmakla mümkündür. Bunun için diğer alanlarda olduğu gibi ekonomi alanında da küresel piyasalarda sıklıkla kullanılan ve dilimizde yeni yeni kullanılmaya başlanan kelime ve terimlere uygun Türkçe karşılıklar bulunmalıdır.

$\mathrm{Bu}$ çalışmada küresel piyasalarda sıkça kullanılan ancak Türkçede yeni kullanılmaya başlanan bazı terimlere Türkçe karşılıklar önerilmiştir. Bu karşılıklar önerilirken öncelikle alıntı terimlerin kökenlerine inilmiş, tarihi gelişim ve değişim sürecinde geçirdikleri fonetik ve morfolojik değişikler açıklanmıştır: hold $>$ hodl, fold $>$ fold gibi. Daha sonra söz konusu terimlerin oluşumunda etkili olan etkenler üzerinde durulmuş ve çalışmaya konu olan terimlerin çoğunun oluşumunda metaforlardan yararlanıldığı tespit edilmiştir. Bu terimlerin bir kısmında yer alan metaforların Türk kültüründe herhangi bir anlam ifade etmedikleri (bull market, liquid market gibi); bazı terimlerdeki metaforların Batı kültüründe ifade ettiği anlamlar ile Türk kültüründe ifade ettikleri anlamlar arasında az da olsa farklılık bulunduğu (widow-and-orphan stock gibi); bazı terimlerde yer alan metaforların Türk kültüründe kullanıldığı fakat farklı şekillerde yer aldığı (headwind(başrüzgâr), tailwind (kuyrukrüzgâr) gibi) tespit edilmiştir. Türk kültüründe herhangi bir anlam ifade etmeyen metaforların yer aldığ terimlere karşılık önerisinde bulunulurken kaynak terimin ifade etiği anlam esas alınmıştır. Batı kültüründe ifade ettiği anlamlar ile Türk kültüründe ifade ettikleri anlamları arasında az da olsa farklılık bulunan terimlere Türkçe karşılık önerisinde bulunulurken varsa yakın anlam ifade eden metaforlardan yararlanılmış, yakın anlam ifade eden metafor yoksa terimin ifade etiği anlam esas alınarak karşılık önerisinde bulunma yoluna gidilmiştir. Benzer anlam taşıyan metaforlardan oluşan terimlere karşılık önerilirken genellikle terimde yer alan metafor muhafaza edilerek karşılık önerisinde bulunulmuştur. Ayrıca çalışmaya konu olan terimlere önerilen Türkçe karşılıkların mümkün olduğunca Türkçede algı sorunu olmayan ve karşılık olarak önerildiği terimlerin anlamını tam olarak yansıtan kelime veya kelime gruplarından oluşmasına özen gösterilmiştir. Böylece bir yandan küresel ekonomi piyasalarında sıkça kullanılan dilimizde henüz yeni kullanılmaya başlanan bazı terimlere Türkçe karşılıklar önerilirken diğer yandan ülkemizde hemen her alanda görülen ve gittikçe bir istilaya dönüşen terimlerde yabancılaşmaya dikkat çekmeye çalışılmıştır.

\section{Küresel ekonomi piyasalarında sıkça kullanılan bazı terimlere Türkçe karşılıklar}

Liquid Market (Likit Market): Fransızca "stvı" anlamındaki "liquide" kelimesi ile İngilizce "pazar, satış yeri, işletme" anlamındaki "market" kelimesinin bir araya getirilmesi ile oluşturulmuş bir kelime grubudur. Bu kelime grubu, küresel ekonomi piyasalarında "kullanılması hemen mümkün olan para" anlamında bir ekonomi terimi olarak kullanılmaktadır. Son zamanlarda Türkiye'de de ekonomi alanında kullanılmaya başlanan bu ekonomi terimine karşılık olarak "nakit piyasası” terimi kullanılabilir.

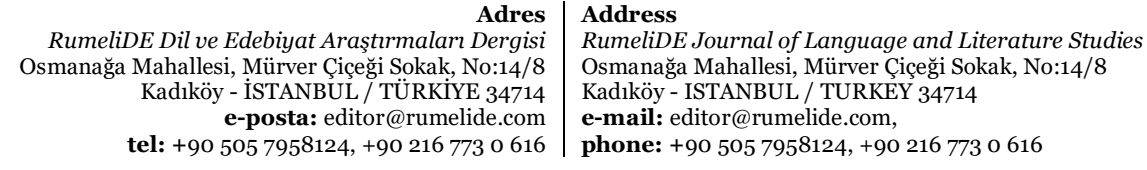


"When you have a hyper liquid market with a hyper volatile movement in price like we've seen across the entire fixed income market, those services lag, added Nadig." (URL1)

Yapılmış çeviri:

"Likit piyasada varlıklar sabit bir fiyattan alınıp satılır ve varlık fiyatlarında önemli bir değişikliğe neden olmaz." (URL1)

\section{Önerilen çeviri:}

"Nakit piyasasında varlıklar sabit bir fiyattan alınıp satılır ve varlık fiyatlarında önemli bir değişikliğe neden olmaz."

Bull Market: İngilizce "boğa" anlamındaki "bull” kelimesi ile yine İngilizce "pazar, satış yeri, işletme, piyasa" anlamındaki "market" kelimesinin bir araya getirilmesi ile oluşturulmuş bir kelime grubudur. $\mathrm{Bu}$ kelime grubu, küresel ekonomi piyasalarında "canlı ve yoğun talepten dolayı fiyatlarm yükseldiği piyasa" anlamında bir ekonomi terimi olarak kullanılmaktadır. Metaforlar somut ya da bilinen bir şeyden faydalanarak soyut veya fazla bilinmeyen bir şeyi anlatma imkânı sunarlar. Dil kullanıcılarına bir görme biçimi sunan metaforlar herhangi bir hususta var olan algıdan hareketle dil kullanıcısına bir düşünce çerçevesi sunar. Bu terim oluşturulurken "gelişme, güç, yükselme, kazanma"yı sembolize eden "boğa" metaforu ile simgesel anlatıma başvurulmuştur. Söz konusu terim, kelime çevirisiyle "boğa piyasası" olarak kullanıldığı takdirde sadece ekonomistler tarafından anlaşılabilir. Terimin normal kültür düzeyine sahip herkes tarafından kolayca anlaşlabilmesi, anlamından hareketle önerilecek bir karşıllk ile mümkündür. Günümüzde Türkiye'de de ekonomi alanında kullanılmaya başlanan bu metaforik ekonomi terimine karşılık olarak "yükselen piyasa” terimi kullanılabilir.

"During the bull market of 2017-2018, top research institutions and acclaimed researchers in China (and elsewhere) set up teams to develop public chains with higher performance requiring large-scale financing." (URL2)

\section{Önerilen Çeviri:}

“2017-2018 yükselen piyasası sırasında, Çin'deki (ve diğer yerlerdeki) en iyi araştırma kurumları ve beğenilen araştırmacılar, büyük ölçekli finansman gerektiren daha yüksek performansa sahip halk zincirleri geliştirmek için ekipler kurdu."

Widow and orphan stock: Old English denilen Eski İngilizcede "boş olmak, muhtaç kalmak" anlamındaki "widewe" kelimesinden türeyen "dul" anlamındaki "widow" kelimesi, Latince kökenli olup Eski Yunancada da kullanılan "yakını ölmüş, öksüz, yetim, öksüz kalmak, yetim kalmak” gibi anlamlarda kullanılan "orphan" kelimesi ve genel anlamı "depolamak, bir yere yığmak, mah belli bir amaç için bir yere toplayıp bekletmek" olan ekonomi alanında "bir değişkenin herhangi bir andaki toplam ya da birikmiş değeri, sermaye, hisse senedi" anlamına gelen "stock" kelimesi ile bir araya getirilmesiyle oluşturulmuş metaforik bir terimdir. Bu terimi oluşturan kelimelerden "stock" kelimesi, günümüzde Türkçede genel olarak "1. Üretilip satışa hazır duruma getirilmiş, depolanmış malların toplam miktarı. 2. Bir sanayi dalında kullamılan hammaddelerin, işlenmiş ya da yar işlenmiş maddelerin tümü. 3. Bir gereksinimi karşılayacak herhangi bir maddeden çok miktarda alarak yığma" anlamlarında (URL3, 1998:2032), ekonomi alanında ise, "stok" şeklinde ve "Depoda yığılı durumda bulunan, satılmamış mal." anlamında kullanılmaktadır. Son zamanlarda küresel piyasalarda sık kullanılmaya başlanan bu terim, buna paralel olarak Türkiye'de de ekonomi alanında kullanılmaya başlanmıştır. Ben Reynolds'a (2015) göre, bu terim ile anılan hisse senetleri, ekonomi alanında "Ailenin geçimini sağlayan kişinin hayatın kaybetmesi durumunda dul ve yetim kalan aileyi beslemek üzere güvenilir bir kâr payı sağlanması amacıyla alınan hisse senetleri”ni karşıladı̆̆ için söz konusu hisseler "dul ve yetim senedi" anlamındaki "widow-and-orphan stock" adıyla terimleştirilmiştir. Adam Heyes'e (2019) göre ise, tarihsel bağlamda, bu tür hisseler çoğunlukla dul ve yetimler veya yüksek riske

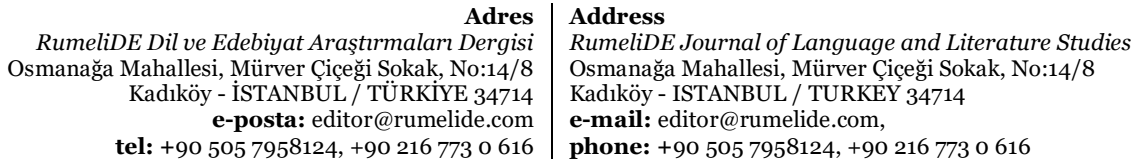


girebilecek kadar bilgi ve cesareti olmayanlar için değerlendirildiğinden söz konusu hisseler bu adla terimleştirilmiştir. Türk kültüründe İslam dininin bu konudaki kesin emirleri gereği dul ve yetimler, korunması ve kollanması gereken zümreler arasında öncelikli olan insanlardır. Ancak toplumumuzda Batı toplumlarında olduğu gibi hisse senedi alma yaygın olmadığı için dul ve yetimlerin korunması ve kollanmasında daha çok bunların sosyal yardımlardan yararlandırılması yoluna gidilir. Bu sebeple, Türk kültüründe "widow-and-orphan stock" teriminde ön planda olan "dul ve yetim" metaforu, alg1 bakımından Batıdaki algıyla uyuşmamaktadır. Dolayısıyla bu terime, daha da yaygınlaşmadan bir Türkçe karşılık bulunmalıdır. Günümüzde Türkiye'de de ekonomi alanında kullanılmaya başlanan ve Zargan Sözlüğü’nde "yüksek teminath kıymetli kağıt” olarak açıklanmaya çalışllan bu metaforik ekonomi terimine karşıllk olarak "kazanç garantili hisse" terimi kullanılabilir.

NEW YORK (The Street) "When it comes to times of uncertainty and volatility, nothing beats "widows and orphans" stocks. What are they? They are dividend stocks with high yields and minimal risk as compared to other stocks." (URL4)

\title{
Önerilen çeviri:
}

NEW YORK (The Street) - "Belirsizlik ve volatilite (fiyatlarda görülen dalgalanma) söz konusu olunca, hiçbir şey "kazanç garantili” hisselerin önüne geçemez."

Volatility: Genel olarak "uçan yaratık, hızlı, çabuk geçen" anlamına gelen Eski Fransızca "volatile” ve Latince "volare, volatilis" kelimelerinden türemiş ve Ortaçağ İngilizcesinde 130o'lü ylllarda "kuşlar, kelebekler ve diğer kanath yaratıklar" olarak benimsenmiş "volatility" kelimesi (URL5), günümüzde sıkça bir ekonomi terimi olarak kullanılmaktadır. Tureng ve Zargan sözlüklerinde "dalgalanma, oynaklk, kararsızlk, uçuculuk, kayganlık” gibi anlamlarda kullanılan bu terim için kesinleşmiş ya da isabetli bir karşllık kullanılmamaktadır. Türkçeye bazen "dalgalanma" şeklinde çevrilen bu terim, "ekonomide dalgalanma" anlamına gelen "fluctuation" kelimesi ile karıştırılmaktadır. "Dalgalanma" terimi daha çok küresel piyasalarda kullanılan "fluctuation" teriminin karşılığı olarak kullanıldığı için "volatility" terimine karşılık olarak "dalgalanma" terimini kullanmak hem anlam karışıklığına yol açacak hem de "volatility" kelimesinin "ansızın, birdenbire gerçekleşme" anlamını yansıtmayacaktır. Bu sebeplerle olsa gerek Türkçe ekonomi sayfalarında genel olarak "volatilite" kelimesi, dalgalanma şeklinde değil, Fransızca aslı olan "volatilite" şeklinde kullanıldığı görülmektedir. Ekonomide daha çok "fiyatlarda görülen ani dalgalanma, oynaklı ve değişkenlik" anlamında kullanılan bu terimde asıl vurgulanan "dalgalanma, oynaklık, değişkenlik"in "ansızın, birdenbire” gerçekleşmesidir. Onun söz konusu terime karşllı bulunurken bu iki husus da göz önünde bulundurulursa "volatility" terimine karşılık olarak “oynaklık” terimi kullanılabilir.

\begin{abstract}
"The firming of growth in developing countries is being bolstered by an acceleration in high-income countries and continued strong growth in China. However, growth prospects remain vulnerable to headwinds from rising global interest rates and potential volatility in capital flows, as the United States Federal Reserve Bank begins withdrawing its massive monetary stimulus"(URL6).
\end{abstract}

\section{Yapılmış çeviri:}

"Yüksek gelirli ülkelerdeki hızlanma ve Çin’in devam edene güçlü büyüme performansı gelişmekte olan ülkelerdeki büyümenin sağlamlaşmasını sağlıyor. Bununla birlikte, büyüme beklentileri, yükselen küresel faiz oranları ve ABD Merkez Bankası'nın büyük ölçekli parasal canlandırma önlemlerini geri çekmeye başlaması ile birlikte sermaye akışlarında yaşanabilecek olası volatilite karşısında kırılganlığını korumaktadır” (URL7).

\section{Önerilen çeviri:}

"Yüksek gelirli ülkelerdeki hızlanma ve Çin’in devam edene güçlü büyüme performansı gelişmekte olan ülkelerdeki büyümenin sağlamlaşmasını sağlıyor. Bununla birlikte, büyüme beklentileri, yükselen küresel faiz oranları ve ABD Merkez Bankası'nın büyük ölçekli parasal canlandırma

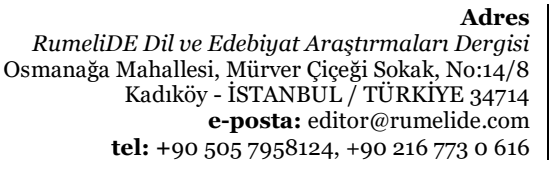

RumeliDE Dil ve Edebiyat Araştırmaları Dergisi Kadlköy - ISTANBUL/TÜRIYE 34714 tel: +90 505 7958124, +902167730616
Address

RumeliDE Journal of Language and Literature Studies

Osmanağa Mahallesi, Mürver Çiçeği Sokak, No:14/8

Kadıköy - ISTANBUL / TURKEY 34714

e-mail: editor@rumelide.com,

phone: +90 $5057958124,+902167730616$ 
önlemlerini geri çekmeye başlaması ile birlikte sermaye akışlarında yaşanabilecek olası oynaklık karşısında kırılganlığını korumaktadır.”

Headwind: İngilizce "baş" anlamına gelen "head" kelimesi ile "rüzgâr" anlamına gelen "wind" kelimelerinin bir araya getirilmesiyle oluşturulan birleşik bir isimdir. Kelime anlamı "başrüzgâr" olan bu birleşik isim, ekonomi terimi olarak "karşıdan esen rüzgâr" anlamına gelmektedir. Söz konusu terimin türetilmesinde "rüzgâr" metaforundan faydalanılmıştır. Bu simgesel anlatımda büyümeyi engelleyen etken olarak "ters yönden esen rüzgâr" metaforu Batı kültürüne uygun olarak "headwind(başrüzgâr)" simgesi ile anlatılarak toplumun hafızasında var olan algıdan yararlanma yoluna gidilmiştir. İngilizce yayın yapan basın kuruluşlarının ekonomi sayfalarında "headwind" terimi, "arka rüzgâr, kuyruk rüzgar" anlamına gelen "tailwind" teriminin zıddı olarak kullanılmaktadır. URL8'de ilk olarak 1709 yllında "karşıdan esen rüzgâr" anlamıyla kullanılan bu terimin günümüzde "büyümeyi zorlaştıran etken" anlamında kullanıldığı belirtilmektedir. Türk kültüründe "ters yönden veya karşıdan esen rüzgâr" metaforu, "engel" anlamında, "arkadan veya ayn yönde esen rüzgâr" metaforu ise "destek" anlamında kullanılmaktadır. Her iki metaforda da "rüzgâr" metaforu "güç" simgesini temsil etmekte, yönü ise niteliğini belirlemektedir. Ancak "ters yönden veya karşıdan esen rüzgâr" "başrüzgâr" olarak değil, daha çok "ters rüzgâr" olarak, "arkadan veya aynı yönde esen rüzgâr" ise " doğru rüzgâr" olarak toplumumuzun hafizasında yer edinmiştir. Ekonominin yanı sıra havacılık alanında da uçağın iniş esnasında ön kısımdan esen rüzgârın etkisiyle yavaşlaması ile bağdaştırılan "kafa rüzgârı" terimi, Türk kültüründe "büyümeyi zorlaştıran etken" anlamında "ters yönden esen rüzgar" yansıtmamaktadır. Bu sebeple aşağıda görüldüğü üzere bazı çevirilerde "headwind” teriminin göz ardı edildiği gözlenmektedir:

\begin{abstract}
"The firming of growth in developing countries is being bolstered by an acceleration in high-income countries and continued strong growth in China. However, growth prospects remain vulnerable to headwinds from rising global interest rates and potential volatility in capital flows, as the United States Federal Reserve Bank begins withdrawing its massive monetary stimulus” (URL9).
\end{abstract}

\title{
Yapılmış çeviri:
}

"Yüksek gelirli ülkelerdeki hızlanma ve Çin’in devam edene güçlü büyüme performansı gelişmekte olan ülkelerdeki büyümenin sağlamlaşmasını sağlıyor. Bununla birlikte, büyüme beklentileri, yükselen küresel faiz oranları ve ABD Merkez Bankası'nın büyük ölçekli parasal canlandırma önlemlerini geri çekmeye başlaması ile birlikte sermaye akışlarında yaşanabilecek olası volatilite karşısında kırılganlığını korumaktadır” (URL1O).

Ekonomi alanında sık kullanılan "headwind" terimi, kelime çevirisiyle "başrüzgar" şeklinde çevrildiğinde toplumumuzun hafızasında algısal karşılığı olmadığı için bir anlam ifade etmeyecektir. Ekonomide "büyümeyi engelleyen etken" anlamında kullanılan bu terimde asll vurgulanan "güç" ve bu "güç”̈̈n yönüdür. Söz konusu terime uygun karşıllk bulunurken bu iki husus göz önünde bulundurulduğunda "büyümeyi engelleyen etken" olarak "ters yönden esen rüzgâr" metaforu kullanılabilir. Bu sebeple söz konusu terimin metaforik çağrışımının idrak edilebilmesi için toplumumuzun hafizasında var olan algıdan yararlanma yoluna gidilmelidir. Bu durumda "rüzgâr" metaforu muhafaza edilerek "ters yönden esen rüzgâr" anlamındaki "headwind" terimine karşllı olarak "ters rüzgâr" terimi kullanılabilir.

Bu karşılık esas alındığında yukarıdaki cümle şöyle Türkçeye çevrilebilir: "Bununla birlikte, büyüme beklentileri, yükselen küresel faiz oranları ve ABD Merkez Bankası'nı büyük ölçekli parasal canlandırma önlemlerini geri çekmeye başlaması ile birlikte sermaye akışlarında yaşanabilecek olası oynaklktan kaynakh ters rüzgâr karşısında kurılganlı̆ımı korumaktadır."

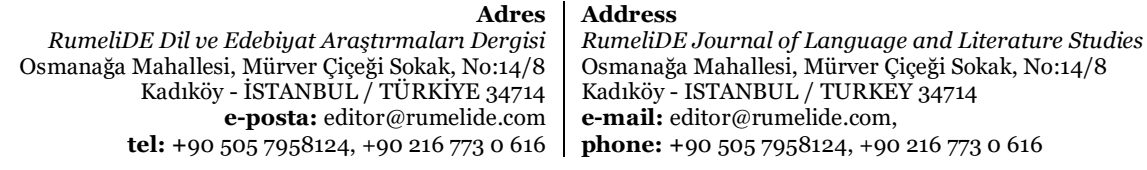


Tailwind: İngilizcede "kuyruk" anlamına gelen "tail" kelimesi ve "rüzgar" anlamına gelen "wind" kelimelerinin bir araya getirilmesiyle oluşturulan birleşik bir isimdir. Kelime anlamı "kuyrukrüzgârı" olan bu birleşik isim, ekonomi terimi olarak "arkadan esen rüzgâr" anlamına gelmektedir. "Tailwind" teriminin türetilmesinde zıddı olan "headwind" teriminde olduğu gibi "rüzgâr" metaforundan faydalanılmıştır. Türk kültüründe "ters yönden veya karşıdan esen rüzgâr" metaforu "engel" anlamında, "arkadan veya aynı yönde esen rüzgâr" metaforu ise "destek" anlamında kullanılmaktadır. Her iki metaforda da "rüzgâr" metaforu "güç" simgesini temsil etmekte, yönü ise niteliğini belirlemektedir. Ekonomide daha çok "büyümeyi destekleyen unsur" anlamında kullanılan bu terimde asıl vurgulanan "güç" ve bu "güç"ün yönüdür. Onun için söz konusu terime uygun karşllık bulunurken bu iki husus göz önünde bulundurulduğunda "büyümeyi destekleyen unsur" olarak "rüzgârı arkasına almak" anlamıyla "arkadan esen rüzgâr" metaforu kullanılabilir. "Tailwind” terimi, kelime çevirisiyle "kuyrukrüzgâr" şeklinde çevrildiği zaman Türkçede bir anlam ifade etmeyecektir. Bu sebeple söz konusu terimin metaforik çağrışımının kolay ve iyi idrak edilebilmesi için toplumumuzun hafızasında var olan algıdan yararlanma yoluna gidilmelidir. Bu durumda "rüzgâr" metaforu muhafaza edilerek "rüzgârı arkasına almak" anlamındaki “tailwind” terimine karşılık olarak "doğru rüzgâr" terimi kullanılabilir.

“Tailwinds fuel the Ashok Leyland stock, but it's a painful ride ahead" (URL11)

\section{Önerilen Çeviri:}

“Doğru rüzgâr Ashok Leyland hissesini teşvik etmekte ancak bu çok da kolay olmayacak.”

Hodl: "Hodl” terimi yakın zamanda literatüre girmiş yeni ve ilginç bir geçmişi olan bir kavramdır. $\mathrm{Bu}$ terimin asıl şekli olan "hold” kelimesi, Ortaçağ İngilizcesinin Eski İngilizceden "haldan (Anglian - Roma dönemi sonrası İngiltere'de yerleşik Germen halkı) ve "healdan” (West Saxon - Wessex Krallı̆̆ı) kelimesinden türetmiş olduğu "halde"” ve sonraki haliyle "holden" kelimelerinden türemiştir (krş. URL12). Jake Frankenfield (2019) tarafından da ifade edildiği üzere, bu terim bitcoin ve diğer kriptoparalar bağlamında "satın alarak elde tutma" stratejilerine atıfta bulunan "hold (elinde bulundurmak)" kelimesinde meydana gelen göçüşme (metatez) sonucu oluşmuş ve terim olarak kullanılmaya başlanınca göçüşme (metatez) sonucu oluşan "hodl” şekli kalıplaşarak kalıcı hale gelmiştir. Esas olarak bir kumar oyunu olan poker terimi şeklinde kullanılagelmiş olan bu kelime, elde bulunan kartlar kazanmaya yeterli görüldügünden ek kart istenmemesi ve elde tutulması anlamını taşımaktadır. Bu açıdan bakıldığında, "fodl” terimi ile birlikte günümüzde ekonomi biliminin önemli bir parçası haline gelen ve bitcoin adlı kriptopara öncülüğünde gittikçe önem kazanan kripto madencilik piyasasının temel terimlerinden biri olan "hodl" terimine Türkçe karşıllk bulunması büyük önem arz etmektedir. İleride daha çok işleklik kazanacak olan ve "satın-al ve elde tut" stratejini ifade eden "hodl" terimine karşıllk olarak "elde tutma" terimi kullanılabilir.

"But as global chaos and social distancing are the order of the day, now, more than ever, you should be thankful you're hodling bitcoin. Here are five reasons why." (URL13)

\section{Yapılmış Çeviri:}

"Uzun vadeli hodl'cı mısınız yoksa kısa vadede kar etmek mi istiyorsunuz? Her iki sorunun cevabı içinde geniş çaplı araştırma yapmak gerekiyor.” (URL14)

\section{Önerilen Çeviri:}

"Uzun vadeli elde tutmadan yana mısınız yoksa kısa vadede kar etmek mi istiyorsunuz? Her iki sorunun cevabı içinde geniş çaplı araştırma yapmak gerekiyor.”

Fodl: "Fodl” kelimesi, yakın dönemde ekonomi literatürüne girmiş ve zıddı olarak kullanılan "hodl” terimi gibi yeni ve ilginç bir geçmişi olan bir terimdir. Bu terimin asıl şekli, Hint-Avrupa dil ailesinin bir

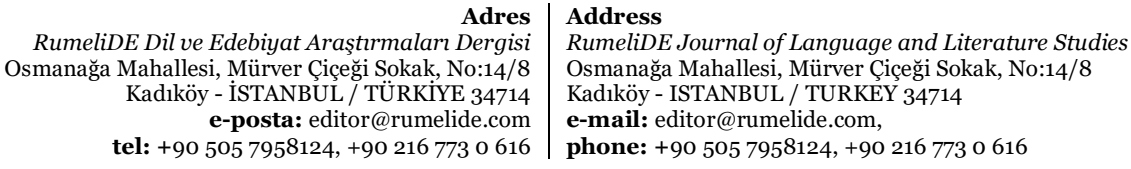


parçası olan Germanik dalının yeniden oluşturulmuş ata dillerinden Proto-Germanic dilindeki "falthan" ve Ortaçağ Felemenkçesindeki "vouden" Flemenkçedeki "vouwen" kelimelerinden türemiş olan "(bezi) katlamak, sarmak, toplamak" anlamı taşıyan "fold” kelimesidir (krş. URL15). "Fodl” terimi de zıddı olan "hodl" terimi gibi göçüşme (metatez) sonucu oluşmuş ve terim olarak kullanılmaya başlanınca göçüşme (metatez) sonucu oluşan "fodl” şekli kalıplaşarak kalıcı hale gelmiştir. Yine zıddı olarak kullanılan "hodl" terimi gibi "fodl" terimi de esasen bir poker oyunu terimi olup poker oyununda daha çok "hold and fold" ikilemi bağlamında kullanılmaktadır. Söz konusu ikilemin ürünü olan bu terimlerden "hold" poker oyununda "kartlarn elde tutulması" anlamını; zıddı olan "fodl" ise, "kartları açarak oyunu sonlandırma" anlamı taşımaktadır. Ekonomide ise "hodl" terimi, "satın alıp elde tutma" stratejisini; "fodl" terimi ise, "zararı arttırmamak için zorunlu elden çıkarma" anlamını taşımaktadır. Günümüzde "hodl” terimi ile birlikte ekonomi alanının önemli parçası haline gelen ve "bitcoin" adlı kriptopara öncülüğünde gün geçtikçe önem kazanan kripto madencilik piyasasının gittikçe işleklik kazanan terimlerinden olan ve "zararı arttırmamak için zorunlu elden çıkarma" stratejisini ifade eden "fodl” terimine karşılık olarak "elden çıkarma” terimi kullanılabilir.

"Many in the last year have probably learned to know what the difference between FOMO and FUD is while everyone is yelling for you to HODL or FODL." (URL16)

\title{
Yapılmış çeviri:
}

"Bu hafta kripto para piyasası 2 HODL ve 1 FODL firsatı sunuyor. Kripto para kışına özel 3 kripto para hakkında okurlarımıza ayrıntılı bilgi vermeye çalışacağız.” (URL17)

\section{Önerilen çeviri:}

"Bu hafta kripto para piyasası 2 ELDE TUTMA ve 1 ELDEN ÇIKARMA firsatı sunuyor. Kripto para kışına özel 3 kripto para hakkında okurlarımıza ayrıntılı bilgi vermeye çalışacağız.”

Antitrust: "Anti” ön eki ve "trust" kelimelerinin bir araya getirilmesiyle oluşan bu terim, Türkçede genellikle "antitröst" şeklinde kullanılmaktadır. Terimi oluşturan iki kelimeden biri olan ve "karşıt" anlamına gelen "anti” kelimesi, Eski Yunanca kökenli olup ön ek görevi görmekte, Sanskritçede "ánti”, Latincede "ante" Ortaçağ Flemenkçesinde "ende" ve İngilizcede "and" şeklinde kullanılmaktadır (krş. URL18). "Trust” kelimesi ise, Old Norse olarak bilinen 9. ve 13. yüzyıllar arasında İskandinav kökenli yerliler tarafından konuşulan North Germanic dilinde "güçlü" anlamına gelen, önceleri "traustr" şeklinde; daha sonra ise, "treysta" ve "traust" şeklinde kullanılan kelimeden türemiştir. Gündelik yaşamda "güven" anlamında kullanılan bu kelime, hukuk dilinde de terim olarak kullanılır. Tureng ve Zargan gibi sözlüklerde "tröst karşıtı", "tröst kurmayı önleyici” gibi anlamlarla açılanmaya çalışlan ve Avrupa Birliği Bakanlığının Avrupa Birliği Terimler Listesi kapsamında rekabet kavramına dayalı ve "antitröst” olarak karşlık bulan bu terimin bu haliyle Türkçede ne ifade ettiği anlaşllamamaktadır. Esasen hukuk terimi olan ve hukuk dilinde " $y a s a$ " anlamındaki "law" kelimesi ile birlikte kullanıldığında -ki çoğu zaman bu haliyle kullanılır- kimi zaman "tekelleşme karşıtı yasalar" kimi zaman ise "tekel karşıtı yasalar" olarak aralarında anlam ayrıntısı olan iki farklı şekilde tercüme edilir. Hem bu karışıklığı önlemek hem de bu terimin son zamanlarda kullanılmaya başlandığı ekonomi alanında yerleşmesini sağlamak için bu terime, ifade ettiği anlamı tam olarak yansıtan Türkçe bir karşllk bulunmalıdır. Günümüzde hukuk dilinde olduğu ekonomi alanında da kullanımı gittikçe artan bu terime karşılık olarak Türkçede “tekelleşme karşıtı” terimi kullanılabilir.

\begin{abstract}
"Earlier this week, the U.S. antitrust agencies extended this concern to the context of the 2019 novel coronavirus (COVID-19) pandemic, issuing a joint statement and press release addressing anticompetitive employment practices during the health crisis and "affirming the importance of competition for American workers." (URL19)
\end{abstract}

\section{Yapılmış çeviri:}

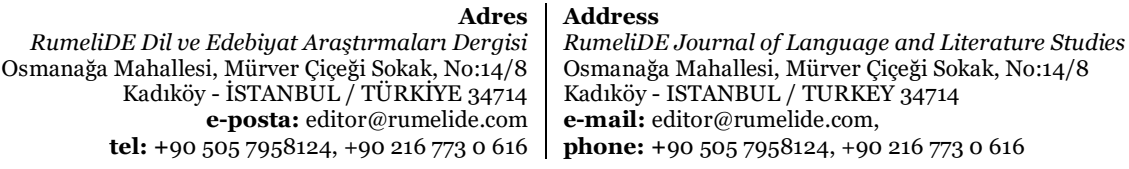

RumeliDE Journal of Language and Literature Studies

Osmanağa Mahallesi, Mürver Çiçeği Sokak, No:14/8

Kadıköy - ISTANBUL / TURKEY 34714

e-mail: editor@rumelide.com,

phone: +90 505 7958124, +90 2167730616 


\begin{abstract}
"Arama devi Google'a yönelik antitröst soruşturmaları devam ederken, yeni ortaya çıan bilgiler Google'ı oldukça zor durumda bırakabilir. Uzmanlar, arama motorunu inceleyerek, arama sonuçlarına beklenenden çok daha fazla müdahale edildiğini ortaya çıkardı.” (URL2O)
\end{abstract}

\title{
Önerilen çeviri:
}

"Arama devi Google'a yönelik tekelleşme karşıtı soruşturmaları devam ederken, yeni ortaya çıkan bilgiler Google'ı oldukça zor durumda bırakabilir. Uzmanlar, arama motorunu inceleyerek, arama sonuçlarına beklenenden çok daha fazla müdahale edildiğini ortaya çıkardı.”

Shill: Tam olarak nerede ve ne zaman ortaya çıtığına dair kesin bir bilgi olmayan ve "shillaber" kelimesinin kısaltılmış hali olarak ortaya çıkan "shill” terimi, 190o'lü yılların başında "kumarcı ya da açlk artırma görevlileri için görev yapan kimse” anlamında ve kuvvetle muhtemel sirk ya da karnaval argosu olarak kullanılmıştır (URL21). Anatoly Liberman (2009)'a göre bir Amerikan argosu olan bu kelimenin "fonfen (bir sahtekârın konuşmaları)" anlamına gelen ve Almanca "schieber (karaborsacl)" anlamına gelen kelimenin genişletilmiş hali olarak "özellikle de bir müşteri kulığında ahcıları teşvik etmek üzere bir suç ortağını özendirerek tuzağa düşürmek” anlamılla kullanılmaktadır. Günümüzde kriptopara borsasının bilinmesi gereken terimlerinin başında gelen "shill”, Türkçeye orijinal haliyle geçmiştir. Cryptominded.com web sitesinde yer alan "Terimler Listesi”nde "shilling" terimi, "piyasaya para ya da dedikodu pompalama" anlamına gelen "pumping” ile eşdeğer anlamda kullanılmakta ve "diğer bir kripto paranın reklamin yapmak üzere görev yapan kimse" anlamı taşıdığı ifade edilmektedir. Günümüzde ekonomi dilinde kullanımı gittikçe artan bu terime karşılık olarak Türkçede "yanıltıcı özendirme" terimi kullanılabilir.

"There are many different regular mining pools, yet they seemingly don't captivate a big audience. Moreover, this "unknown" entity has not tried to "shill" Bitcoin SV in any way on social media." (URL22)

\section{Yapılmış çeviri:}

“Reuters: Para İle Kripto Para ”Shillemek”, Çok Daha Yaygın Bir Hal Alıyor” (URL23)

\section{Önerilen çeviri:}

“Reuters: Para İle Kripto Para Piyasasını "Yanıltıcı Özendirme”, Çok Daha Yaygın Bir Hal Alıyor"

Zero sum game: Will Kenton'a (2020) göre, kelime anlamı "ssfir toplaml oyun" olan "zero sum game" ya da "zero sum" şeklinde kullanılan kelime grubu, terim olarak "bir kişinin kazancmın başka bir kimsenin kaybı ile eşdeğer olduğu bir oyun teorisi kapsammdaki durum" anlamında kullanılır. Net kazancı sıfır olan bir başka deyişle kazancı olmayan, iki oyuncu ile oynanabileceği gibi milyonlarca katılımcının da dâhil olabileceği bir oyundur. Eric Reed (2018), bu oyun teorisinin çoğu uygulamasını ekonomi ve siyaset kuramında bulduğunu öne sürmektedir. Reed'e göre, "sıfır toplamlı oyun" teorisinin genel özellikleri arasında talebin kaynak arzını aşması, genişlemeyen ve daralmayan bir kaynak havuzunun olması ve her katılımcı için sıfır değişim olması gibi kuralları vardır (a.g.e., 2018). Bu teoriyi daha iyi kavrayabilmek için her "zero" ve "sum" kelimelerinin etimolojik durumunu irdelemek ve bunların mevcut ekonomik anlamlandırmalarının altını çizmekte yarar vardır. Johanna Mayer (2018) 'e göre, İngilizcede "gizli yapılmış şey" anlamına gelen "cipher" kelimesi ilk olarak 1598 ylında kullanılmıştır. Söz konusu kelime Arapça "sifr" kelimesinden türemiştir. URL24"te ise, Arapça simgelemi açısından "hiçliği vurgulayan değer" ya da "nicelik olarak değerlendirilen tüm niceliklerin hiçliği, yokluğu” olarak tanımlanan "zero (sıfır)" terimi, Arapça "sifr”, Ortaçağ Latincesinde "zephirum", İtalyancada "zero" ve Fransızca "zéro" şeklinde kullanılır. "Sum" kelimesi ise "toplam, netice, doruk" anlamlarına gelir. URL25'e göre, Latincede "en yüksek" anlamına gelen, dişil hali "summus" eril hali ise "summa" şeklinde olan kelimeden türemiş, Fransızcada "sume, somme"; Ortaçă̆ İngilizcesinde ise, "summe" şeklinde kullanılmıştır. Ülkemizde de ekonomi alanında kullanılmaya başlanan "zero sum

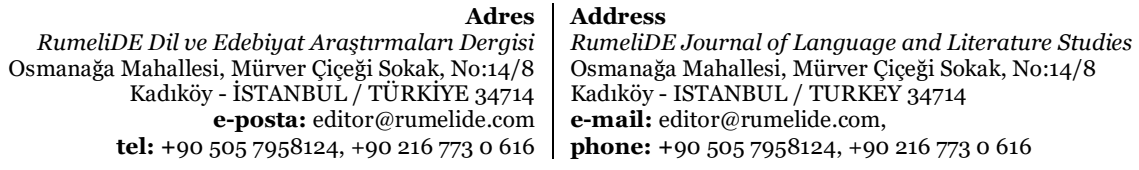


game" ya da "zero sum" terimine karşıllk olarak Türkçede "sıfır sonuçlu oyun" terimi kullanılabilir.

\begin{abstract}
"And, theoretically, the BOT has to absorb the new cash back to prevent inflation. It is a zero-sum game for the economy. Therefore, the focus should be on the 1 trillion baht in government borrowing." (URL26)
\end{abstract}

\title{
Yapılmış çeviri:
}

"Bir de "risk iştahı" diye bir şey uydurduk ki bu bana kalırsa ekonominin özü ile tamamen çelişen ve ekonomiyi "sıfır toplamlı bir oyun" haline getiren bir kavramdır. Oysa ekonomi özünde karşılıklı kazanmaya dayanan ve gün sonunda herkesin kazandığı bir mekanizma olmalıydı.” (URL27)

\section{Önerilen çeviri:}

"Bir de "risk iştahı" diye bir şey uydurduk ki bu bana kalırsa ekonominin özü ile tamamen çelişen ve ekonomiyi bir "sıfır sonuçlu oyun" haline getiren bir kavramdır. Oysa ekonomi özünde karşılıklı kazanmaya dayanan ve gün sonunda herkesin kazandı̆̆ı bir mekanizma olmalıydı.”

\section{Sonuç}

Günümüzde küreselleşme ile global bir köy haline gelen dünyada toplumlararası çok hızlı bilgi akışı yaşanmaktadır. Bu bilgi akışı çeviriyle değişik diller konuşan toplumlara anlık iletilmektedir. Böylece hayatımıza her gün birçok yeni kavram ve bu kavramları karşılayan kelime ve terimler girmektedir. Bu kelime ve terimler başta çeviri olmak üzere çeşitli yollarla dile girmekte, daha sonra yaygınlaşıp kendilerine algı oluşturunca dile yerleşmektedir. Böylelikle yabancı dillerden özellikle Batı kaynaklı yabancı dillerden Türkçeye her gün başta tercüme olmak üzere çeşitli yollarla onlarca yeni kelime ve terim girmektedir. Günümüzde Türkçe kelime ve terim türetme ve bunları yayma çalışmaları durma noktasına geldiğinden söz konusu kelime ve terimler, kısa süre sonra yaygınlaşıp dile yerleşmektedir. Bu duruma başta terim kalabalığı olmak üzere tutarsızlık ve keyfiliklerden kaynaklanan sorunlar da eklenince ithal kelime ve terim kullanımı makul düzeyi aşarak tam anlamıyla bir istila haline gelmiştir.

Dil bilinci olan hemen herkes, bugün neredeyse bütün bilim, sanat ve spor dallarında yaşanan Batı dilleri kaynaklı kelime ve terim istilasının farkındadır. Gün, geçmiş tecrübeler ışı̆̆ında söz konusu istilaya çözüm bulma günüdür. Türkçe yaşadığı bu istiladan ancak daha önce yapılan yanlışlara düşülmeden geçmiş tecrübelerin ışı̆̆ında yeni bir ruh, dayanışma ve işbirliği ile kurtulabilir. Türkçeyi korumak, yabancı kelime ve terim istilasından kurtarmak, ilgili kurum, kuruluş ve uzmanların iş birliğini gerektiren geniş kapsamlı bir çalışmayla mümkündür. Ancak günümüzde söz konusu işbirliği için gereken ortam olmadığı için katkısı olabilecek herkes, vahameti her geçen gün derinleştiğinden acil çözüm gerektiren bu istilaya çözüm bulmaya yoğunlaşmalı, söz konusu sorunun çözümüne yönelik gayret sarf etmelidir. Bu gayretin bir parçası olarak gündelik yaşamın en hızlı küreselleşen alanlardan biri olan ekonomi alanında Türkçede yeni ve sıkça kullanılmaya başlanan aşağıdaki alıntı kelime ve terimlere Türkçenin ifade kabiliyeti, kullanışllıı ve işlevsellik esas alınarak Türkçe karşllıklar önerilmiştir. Bu kapsamda Türkçe karşılık önerilen kelime ve terimler şunlardır:

\begin{tabular}{|l|l|l|}
\hline Kaynak Terim & İfade Ettiği Anlam & $\begin{array}{l}\text { Türkçe } \\
\text { Karşılı̆̆ }\end{array}$ \\
\hline liquid market & Kullanılması hemen mümkün olan para. & nakit piyasası \\
\hline bull market & Canlı ve yoğun talepten dolayı fiyatların yükseldiği piyasa. & $\begin{array}{l}\text { yükselen } \\
\text { piyasa }\end{array}$ \\
\hline
\end{tabular}

\footnotetext{
\begin{tabular}{r|l} 
Adres & Address \\
RumeliDE Dil ve Edebiyat Araştırmaları Dergisi & RumeliDE Journal of Language and Literature Studies
\end{tabular} Osmanağa Mahallesi, Mürver Çiçeği Sokak, No:14/8 $\quad$ Osmanağa Mahallesi, Mürver Çiçeği Sokak, No:14/8 Kadıköy - ISTANBUL / TURKIYE 34714 Kadıköy - ISTANBUL / TURKEY 34714 e-posta: editor@rumelide.com e-mail: editor@rumelide.com, tel: +90 505 7958124, +90 2167730616 phone: +90 505 7958124, +90 2167730616
} 


\begin{tabular}{|l|l|l|}
\hline $\begin{array}{l}\text { widow-and- } \\
\text { orphan stock }\end{array}$ & $\begin{array}{l}\text { Ailenin geçimini sağlayan kişinin hayatını kaybetmesi durumunda } \\
\text { kalan dul ve yetimleri beslemek üzere güvenilir bir kâr payı } \\
\text { sağlanması amacıyla alman hisse. }\end{array}$ & $\begin{array}{l}\text { kazanç } \\
\text { garantili hisse }\end{array}$ \\
\hline volatility & Fìyatlarda görülen ani dalgalanma, oynaklık ve değişkenlik & oynaklık \\
\hline headwind & Büyümeyi zorlaştıran etken /karşıdan esen rüzgâr & ters rüzgâr \\
\hline tailwind & Büyümeyi destekleyen unsur rüzgârı arkasına almak & doğru rüzgâr \\
\hline hodl & Satın alıp elde tutma. & elde tutma \\
\hline fodl & Zararı arttırmamak için zorunlu elden çıkarma. & elden çıarma \\
\hline antitrust & Tekelleşmeyi önleme amacıyla yapılan. & $\begin{array}{l}\text { tekelleşme } \\
\text { karşıtı }\end{array}$ \\
\hline shill & Diğer bir kripto paranın reklamını yapmak üzere yapılan hamle. & $\begin{array}{l}\text { yanıltıcı } \\
\text { özendirme }\end{array}$ \\
\hline zero sum game & $\begin{array}{l}\text { Bir kişinin kazanctnın başka bir kimsenin kaybı ile eşdeğer olduğu } \\
\text { oyun. }\end{array}$ & $\begin{array}{l}\text { sifur sonuçlu } \\
\text { oyun }\end{array}$ \\
\hline
\end{tabular}

Çevirilerde genellikle görmezden gelinen ya da orijinal şekilleriyle kullanılan yukarıdaki alıntı kelime ve terimlerin yerine bu çalışmayla önerilen Türkçe karşılıklarının kullanılması, Türkçeyi Batı kaynaklı yabancı dillerden alıntı kelime ve terimlerin istilasından kurtarmaya katkı sağlayacaktır.

\section{Kaynakça}

Bulak, Şahap (2012). Kelime Türetme ve Bir Kelime Türetme Önerisi: Çaysa- Üzerine. The Journal of Academic Social Science Studies International Journal of Social Science Volume 5 Issue 1, February 2012, s. 63-74.

Bulak, Şahap (2013). Türkçenin Sadeleştirilmesinde Yanlış Ek Kullanımı veya Eklerin Yanlış Kullanilmas. The Journal of Academic Social Science Studies International Journal of Social Science Volume 6 Issue 3, s. 57-76, March 2013.

Bulak, Şahap (2017). Türkçe Öğretiminde Terim Sorun. Uluslararası Türk Dili ve Edebiyatı Bilgi Şöleni, Atatürk Üniversitesi, 12-14 Mayıs 2017, Erzurum.

Cryptominded, A Glossary of all the Cryptocurrency Terms you need to know, https://cryptominded.com/glossary-cryptocurrency-terms-need-know/(E.T.14/04/2020).

Demir, Celal (2006). Türkçe Dil Bilgisinde Terminoloji Sorunu. Türk Dili Araştırmaları Yıllı̆̆ı-Belleten $54(2006 / 1), 81-100$.

Dilaçar, Agop (1957). Terim Nedir. Türk Dili, C IV, Ankara, s. 60-78.

Dizdaroğlu, Hikmet (1988). Terimler Üzerine. Dil Yazıları I, Türk Tarih Kurumu, Basımevi, Ankara.

Elıot, T. S. (1941). Four Quartets. Harcourt, Us.

Fan, H. (2017). Strategies for Translation of English Commercial Advertisements from the Intercultural Perspective. Open Journal of Social Sciences, 5, 38-45, http://www.scirp.org/journal/jss

Frankenfield, Jake (2019). Hodl https://www.investopedia.com/terms/h/hodl.asp

Heyes, Adam (2019). Widow-and-Orphan Stock, Retrieved from https://www.investopedia.com/terms/w/widowandorphanstock.asp

Jue, X. (2009). Economic Metaphors in English Newspapers. English Linguistic C-essay, Kristianstad University College.

Kenton, Will (2020). Zero-Sum Game, https://www.investopedia.com/terms/z/ zero-sumgame.asp

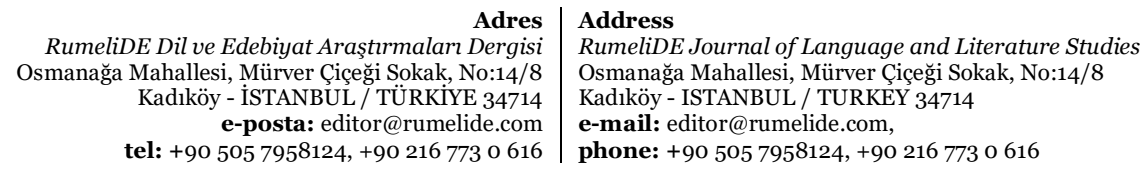


Liberman, Anatoly (2009). British Slang of Jewish Origin (?): Oof and Fefnicute, https://blog.oup.com/2009/o9/oof_fefnicute/

Mayer, Johanna (2018). The Origin of The Word “Zero". https://www.sciencefriday.com/articles/theorigin-of-the-word-zero/

Parasuk, Chartchai (2020). Covid-19 stimulus may sink economy, https://www.bangkokpost.com/opinion/opinion/1896190/covid-19-stimulus-may-sinkeconomy

Pilav, Sami (2008). Terim Sorunu ve Eğitim Öğretimde Terimlerin Yeri ve Önemi. Kastamonu Eğitim Dergisi, Mart 2008 Cilt:16 Sayı:1 s.267-276.

Reed, Eric (2018). What Is a Zero Sum Game and Why Is It Important in 2019?., https://www.thestreet.com/politics/what-is-a-zero-sum-game-14818535

Reynolds, Ben (2015). 3 High-Yield, Low-Risk Dividend Stocks for Extreme Safety, https://www.thestreet.com/opinion/3-high-yield-low-risk-dividend-stocks-for-extrem-safety13165126

TC Avrupa Birliği Genel Sekreterliği (2009). Avrupa Birliği Terimleri Sözlüğü (İngilizce-Türkçe) Glossary For The European Unıon (English-Turkish). Matus Basım Evi. Ankara.

Timurtaş, Faruk Kadri (1966). Terimlerin Türkçeleştirilmesi. Türk Dili, TK.44, Ankara.

Yabancı Kelimelere Karşılıklar, Türk Dil kurumu Yayınları, Ankara, 2002.

Yılmaz, Levent (2020). Ekonomik Savaş, Kur Savaşları Ve Yeni Küresel Kriz, https://www.yenisafak.com/yazarlar/leventyilmaz/ekonomik-savas-kur-savaslari-ve-yenikuresel-kriz-2054191

\section{URL listesi}

URL1: https://www.cnbc.com/2020/03/26/coronavirus-bond-market-pricing-not-recognizing-newreality.html

URL2: https://www.haberturk.com/likidite-nedir-likiditenin-ekonomik-onemi-nedir-likidite-tuzaginedir-1982974

URL3: https://cryptobriefing.com/crypto-cycles-a-shift-in-investment-logic-in-the-digital-currencymarket/

URL4: Türkçe Sözlük I-II, Türk Dil kurumu Yayınları, Ankara, 1998.

URL5: https://www.thestreet.com/opinion/3-high-yield-low-risk-dividend-stocks-for-extreme-safety13165126 E.T. 12.04 .2020

URL6: https://www.etymonline.com/word/volatile

URL7: https://www.worldbank.org/en/news/press-release/2014/01/14/global-economy-turningpoint-world-bank

URL8: https://www.worldbank.org/tr/news/press-release/2014/o1/14/global-economy-turningpoint-world-bank

URL9: https://www.merriam-webster.com/dictionary/headwind

URL10: https://www.worldbank.org/en/news/press-release/2014/o1/14/global-economy-turningpoint-world-bank

URL11: https://www.worldbank.org/tr/news/press-release/2014/o1/14/global-economy-turningpoint-world-bank

URL12: https://www.livemint.com/market/mark-to-market/tailwinds-fuel-ashok-leyland-stock-butit-s-a-painful-ride-ahead-11586350803429.html

URL13: https://www.etymonline.com/word/hold

URL14: https://bitcoinist.com/5-reasons-to-be-happy-if-you-hodl-bitcoin/

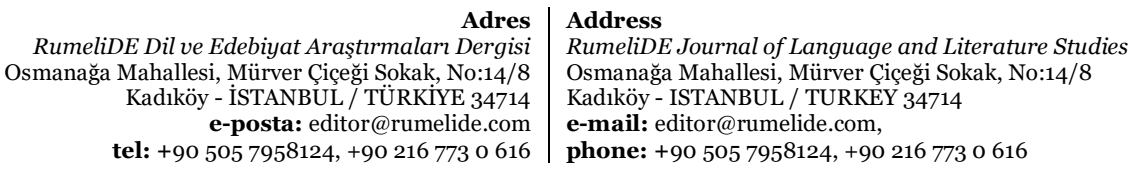


URL15: https://www.coinkolik.com/2020-uzun-vadeli-yatirim-yapilabilecek-kripto-paralar-ve-fiyattahminleri/

URL16: https://www.etymonline.com/search?q=Fold

URL17: https://bitcoinexchangeguide.com/cryptocurrency-trading-terms/

URL18: https://koinmedya.com/2018/11/25/kripto-para-kara-kisina-ozel-2-hodl-1-fodl/

URL19: https://www.dictionary.com/browse/anti

URL20: https://www.natlawreview.com/article/antitrust-regulators-warn-against-anticompetitiveemployer-practices-during-pandemic

URL21:_https://www.ensonhaber.com/googlein-arama-sonuclarina-mudahale-ettigi-ortaya-cikti.html

URL22: https://www.etymonline.com/word/shill

URL23: https://winkreport.com/bitcoin-sv-mining-pools-lose-the-battle-against-unknown-miners\%E2\%80\%A2-cryptomode/

URL24: https://koinbulteni.com/reuters-para-ile-kripto-para-shillemek-cok-daha-yaygin-bir-halaliyor-31394.html

URL25: https://www.etymonline.com/word/zero\#etymonline_v_5012

URL26: https://www.merriam-webster.com/dictionary/sum

URL27: https://www.bangkokpost.com/opinion/opinion/1896190/covid-19-stimulus-may-sinkeconomy

URL28: https://www.yenisafak.com/yazarlar/leventyilmaz/ekonomik-savas-kur-savaslari-ve-yenikuresel-kriz-2054191

RumeliDE Dil ve Edebiyat Araştırmaları Dergisi Osmanağa Mahallesi, Mürver Çiçeği Sokak, No:14/8 Kadıköy - İSTANBUL / TÜRKIYE 34714 e-posta: editor@rumelide.com tel: +90 $5057958124,+902167730616$
Address

RumeliDE Journal of Language and Literature Studies

Osmanağa Mahallesi, Mürver Çiçeği Sokak, No:14/8

Kadıköy - ISTANBUL / TURKEY 34714

e-mail: editor@rumelide.com,

phone: +90 505 7958124, +90 2167730616 